\title{
ARTICLES
}

\section{Cytomegalovirus (CMV) Inactivation in Breast Milk: Reassessment of Pasteurization and Freeze-Thawing}

\author{
KLAUS HAMPRECHT, JENS MASCHMANN, DENISE MÜLLER, KLAUS DIETZ, \\ INGO BESENTHAL, RANGMAR GOELZ, JAAP M. MIDDELDORP, CHRISTIAN P. SPEER, \\ GERHARD JAHN
}

Institute of Medical Virology and Epidemiology of Viral Diseases [K.H., D.M., G.J.], Department of Medical Biometry [K.D.], Central Laboratory [I.B.], and Department of Neonatology [R.G.], University

Hosital of Tübingen, 72076 Tübingen, Germany, Children's Hospital [J.M., C.P.S.], University of Würzburg, 97080 Würzburg, Germany, and Department of Pathology [J.M.M.], VU Medical Center, 1007

MB Amsterdam, The Netherlands

\begin{abstract}
Breast-feeding mothers frequently transmit cytomegalovirus (CMV) to preterm infants of very low birth weight. Current recommendations for prevention of virus transmission are based on data published $20 \mathrm{y}$ ago in the context of human milk banking. Two recent clinical trials examined storage of breast milk at $-20^{\circ} \mathrm{C}$ to reduce virus transmission. However, in both studies, CMV transmission occurred. Using sensitive tools like quantitative PCR, CMV pp67 late mRNA assay, and a high-speed, centrifugation-based microculture assay for quantification of CMV infectivity, we reassessed the virological and biochemical characteristics of freeze-storing breast milk at $-20^{\circ} \mathrm{C}$, compared it with traditional Holder pasteurization $\left(30 \mathrm{~min}\right.$ at $62.5^{\circ} \mathrm{C}$ ), and a new short-term pasteurization $\left(5 \mathrm{~s}\right.$ at $\left.72^{\circ} \mathrm{C}\right)$ based on the generation of a milk film. Both heat treatment procedures were able to destroy viral infectivity and pp67 RNA completely. Preliminary results showed short-term heat inactivation below $72^{\circ} \mathrm{C}$ was less harmful in reducing the activity of marker enzymes than Holder pasteurization. Freezing breast milk pre-
\end{abstract}

\section{ABSTRACT}

served the biochemical and immunologic quality of the milk; however, late viral RNA and viral infectivity was also preserved. Compared with viral DNA, CMV-RNA more directly reflects infectious $\mathrm{CMV}$ in human milk samples. Further studies are necessary to evaluate short-term heat treatment below $72^{\circ} \mathrm{C}$ as an effective tool for prevention of CMV transmission. (Pediatr Res 56: 529-535, 2004)

AP, alkaline phosphatase

CMV, cytomegalovirus

HFF, human foreskin fibroblasts

IE, immediate early

NASBA, nucleic acid sequence-based amplification

p.p., post partum

SIgA, secretory IgA

VLBW, very low birth weight
Breast-feeding in premature infants is beneficial (1). However, breast-feeding of a high-risk group of preterm infants (birth weight $<1000 \mathrm{~g}$, gestational age at birth $<30 \mathrm{wk}$ ) may be associated with symptomatic CMV infection $(2,3)$. If CMV trans-

Received July 4, 2003; accepted March 17, 2004

Correspondence: Klaus Hamprecht, M.D., Ph.D., Institute of Medical Virology and Epidemiology of Viral Diseases, University Hospital of Tübingen, Elfriede-AulhornStrasse 6, 72076 Tübingen, Germany; e-mail: kshampre@med.uni-tuebingen.de

Supported by grant HA 1559/2-1 from Deutsche Forschungsgemeinschaft, Bonn, Germany.

DOI: 10.1203/01.PDR.0000139483.35087.BE mission from breast milk to preterm infants is clinically important, then prevention of virus transmission will be critical (4).

Recent recommendations for virus inactivation in human milk by freezing, which destroys the virus $(5,6)$, are still based on three studies that evaluated freezing for viral decontamination of stored milk in the context of human milk banking $20 \mathrm{y}$ ago (7-9). Only two studies analyzed the effect of storage at $-20^{\circ} \mathrm{C}$ using naturally infected milk specimens $(8,9)$. Storage of milk for $3 \mathrm{~d}$ at $-20^{\circ} \mathrm{C}$ reduced the viral titre by more than $99 \%$ (9), and storage of naturally infected milk specimens for $7 \mathrm{~d}$ or longer at $-20^{\circ} \mathrm{C}$ eliminated infectivity (8). On the other hand, CMV survived when the milk sample was frozen at 
$-15^{\circ} \mathrm{C}$ for $10 \mathrm{~d}$ in the presence of low lipase levels (7). Interestingly, the persistence of viral infectivity or the enhanced CMV recovery after overnight storage at $4^{\circ} \mathrm{C}$ was discussed in the context of cell-free or cell-associated virus (8). Recent analysis revealed that cell-free virus is present in nearly every seropositive milk (2).

In contrast, Holder pasteurization $\left(30 \mathrm{~min}\right.$ at $\left.62.5^{\circ} \mathrm{C}\right)$ markedly diminished pathogenic bacteria and also completely destroyed CMV infectivity in human milk (7-9). However, heating of spiked milk at $56^{\circ} \mathrm{C}$ for 30 min was not able to reliably eliminate viral infectivity $(7,8)$. Using a modified plate heat exchanger designed for treating large volumes of cow milk, at least $5 \mathrm{~s}$ of heating at $72^{\circ} \mathrm{C}$ was necessary to eliminate $\mathrm{CMV}$ infectivity. This treatment supposedly did not destroy the nutritional and immunologic qualities of human milk (10).

Recently, routine freezing of breast milk at $-20^{\circ} \mathrm{C}$ was recommended to prevent transmission of CMV from breast milk of seropositive mothers to uninfected preterm infants (11). This study was also based on previous data of CMV cryoinactivation $(8,9)$. Using new and very sensitive tools for quantitative detection of CMV in human milk, we reassessed and compared the effectiveness of Holder pasteurization and freezing for CMV inactivation with our new short-term heating procedure based on the generation of a milk film. Biochemical analysis revealed the influence of all three inactivation procedures on the nutritional and immunologic milk quality. Shortterm heat inactivation using temperatures below $72^{\circ} \mathrm{C}$ seemed to be superior to Holder pasteurization, whereas cryoinactivation reduced viral infectivity very insufficiently - especially during physiologic peak level of viral load.

\section{METHODS}

Milk samples. For inactivation, sequential $60-80 \mathrm{~mL}$ samples of freshly expressed milk from each of two seropositive and two seronegative mothers from our study (2) and two healthy volunteers of term infants (one mother seronegative, one mother seropositive transmitter) were used for 10 freezing experiments with storage at $-20^{\circ} \mathrm{C}$ for up to $10 \mathrm{~d}(18 \mathrm{~h}$, $\left.-20^{\circ} \mathrm{C}, n=2 ; 4 \mathrm{~d},-20^{\circ} \mathrm{C}, n=5 ; 10 \mathrm{~d},-20^{\circ} \mathrm{C}, n=3\right), 4$ Holder pasteurization experiments, and 14 short-term pasteurizations with heating for $10 \mathrm{~s}(n=6)$ and $5 \mathrm{~s}$ at $72^{\circ} \mathrm{C}(n=8)$, respectively. Another $120 \mathrm{~mL}$ of seronegative milk were used for a spiking experiment comparing Holder pasteurization with short-term heat inactivation below $72^{\circ} \mathrm{C}$. Informed consent for breast milk donation was obtained from all lactating mothers. This study was approved by the local ethical committee.

Virus spiking experiments. Raw milk samples from seronegative mothers were spiked with an inoculum of cell-free culture supernatant $(3000 \mathrm{~g}$ ) of CMV laboratory strain AD 169 using $10^{4}-10^{5} \mathrm{TCID}_{50}$ (tissue culture infective dose $50 \%$ ) per milliliter raw milk.

Preparation of milk whey and milk fat. Naturally infected milk from seropositive CMV reactivating mothers and spiked milk from seronegative mothers was separated according to previously published protocols $(12,13)$.

Quantitative detection of viral DNA in milk. Viral DNA load (copies $/ \mathrm{mL}$ ) was determined by quantitative PCR (CO-
BAS Amplicor CMV Monitor Test; Roche Molecular Biochemicals, Mannheim, Germany) using milk whey from naturally infected milk and spiked milk after virus inoculation (13).

Quantitative detection of viral infectivity in milk. CMV present in the milk whey fraction was concentrated by centrifugation of $2 \times 1 \mathrm{~mL}$ whey for $1 \mathrm{~h}$ at $50,000 \mathrm{~g}$. Resuspended pellets were inoculated on microcultures of HFF for detection of virus infectivity after $18 \mathrm{~h}$ or $5 \mathrm{~d}$ incubation at $37^{\circ} \mathrm{C}$ and $5 \%$ $\mathrm{CO}_{2}$. Long-term incubation allowed detection of CMV plaque formation, which is associated with fully replication-competent virus. Read-out was the number of specific CMV immediate early antigen-(IEA) stained nuclei $(18 \mathrm{~h})$ or plaques $(5 \mathrm{~d})$ per milliliter whey (virus load) (13).

Detection of CMV pp67 late mRNA in milk. Viral late pp67 mRNA was detected in naturally infected milk whey using the NASBA technique (NucliSens CMV, Organon Teknika, Boxtel, The Netherlands) (14). Therefore, immediately after preparation of milk whey, $100 \mu \mathrm{L}$ were added to $900 \mu \mathrm{L}$ of NASBA lysis buffer [4.7 M guanidinium thiocyanate, $46 \mathrm{mM}$ Tris, pH 6.4, 20 mM EDTA, 1.2\% (wt/vol) Triton X-100], and the mixture was stored at $-70^{\circ} \mathrm{C}$ until further processing (13).

Short-term heat inactivation. This procedure for processing individual milk samples is technically based on the generation of a thin milk film by rotating at least $20 \mathrm{~mL}$ of raw milk in special heating and cooling devices. The heating and cooling process was performed automatically in the following sequence: heat-up time was approximately $90 \mathrm{~s}$, followed by a ramp temperature of $72^{\circ} \mathrm{C}$ (or $62-65^{\circ} \mathrm{C}$ ) for $5 \mathrm{~s}$ (or less) and cooling for $30 \mathrm{~s}$ at $5^{\circ} \mathrm{C}$ to reach $30^{\circ} \mathrm{C}$. The machine (Klaus Lauf, Tübingen, Germany) and the procedure are presented in detail elsewhere (International Patent Application WO 00/74494).

Holder pasteurization. Each $20 \mathrm{~mL}$ sample of naturally infected milk and spiked milk specimens was incubated for 30 $\min$ at $62.5^{\circ} \mathrm{C}$ in a water bath using the LABU-Muttermilchpasteur (Labor Buchrucker, Ottensheim, Austria).

Cryoinactivation. Each $20 \mathrm{~mL}$ sample of milk was frozen in a household freezer at $-20^{\circ} \mathrm{C}$ and stored for $18 \mathrm{~h}, 4 \mathrm{~d}$, and $10 \mathrm{~d}$, respectively. Thereafter, the milk whey fraction was prepared for further analysis.

Biochemical analysis. Total protein concentration and activity of AP and lipase was determined by standard procedures (Roche Molecular Biochemicals) using a Hitachi 917 Automatic Analyzer. Folic acid and vitamin B12 concentrations were determined by chemiluminescence immunoassays using an Advia Centaur Analyzer (Bayer, Leverkusen, Germany). Levels of sIgA and lysozyme were quantified by radial immunodiffusion (The Binding Site, Heidelberg, Germany) and evaluated using a plate reader.

Statistical analysis. Continuous variables were expressed as a percentage of control. All five treatment methods were compared with respect to virus load by the nonparametric Kruskal-Wallis test. Four of the treatment methods were compared with respect to the biochemical variables by an ANOVA of the log-transformed data. The results were back-transformed for easier interpretation. Relative frequencies were compared using Fisher's exact test. 
A

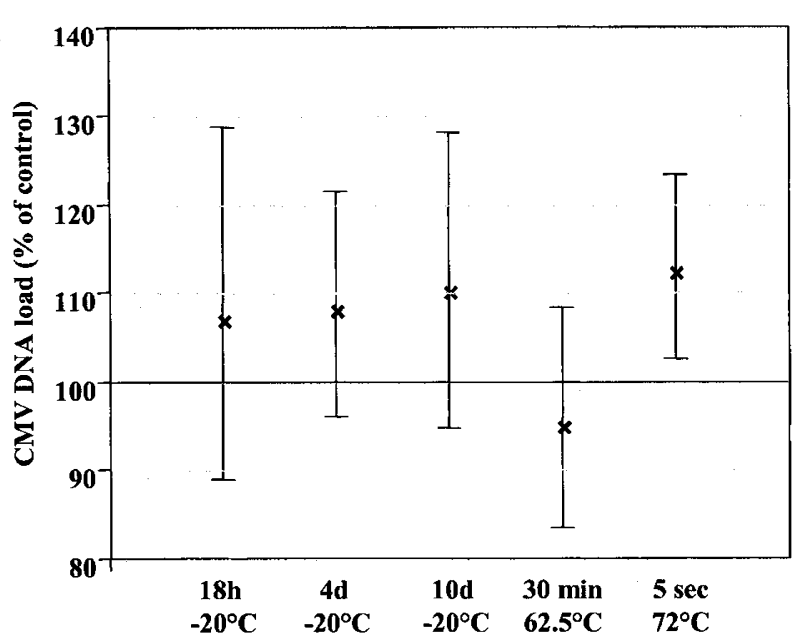

C

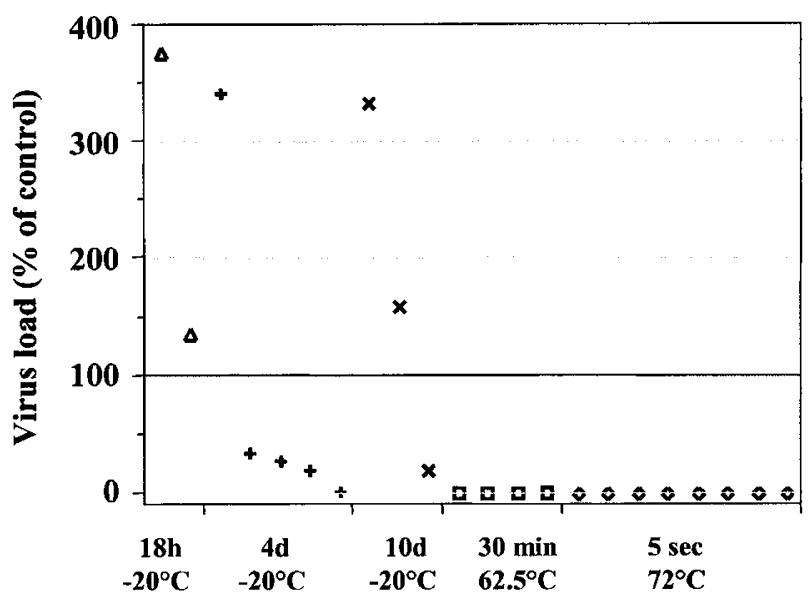

B

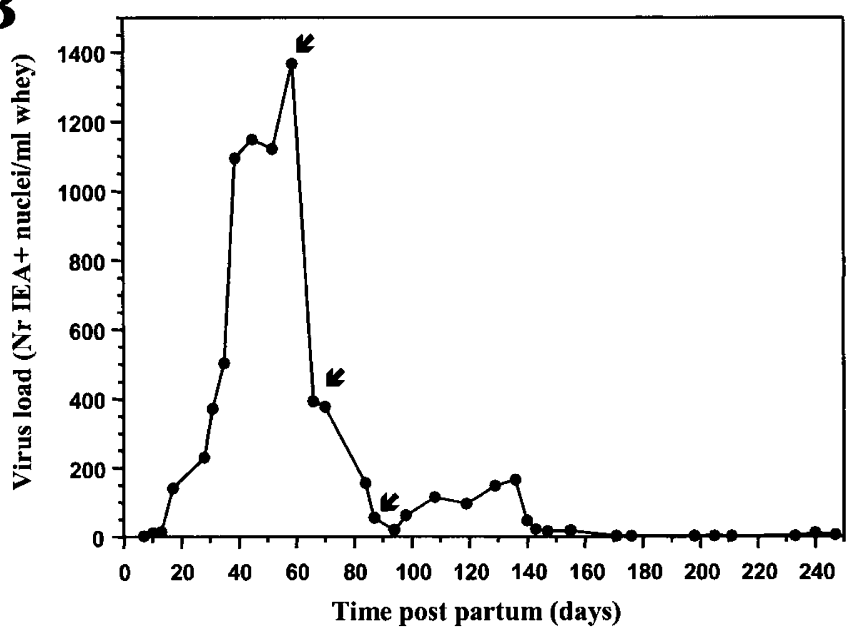

D

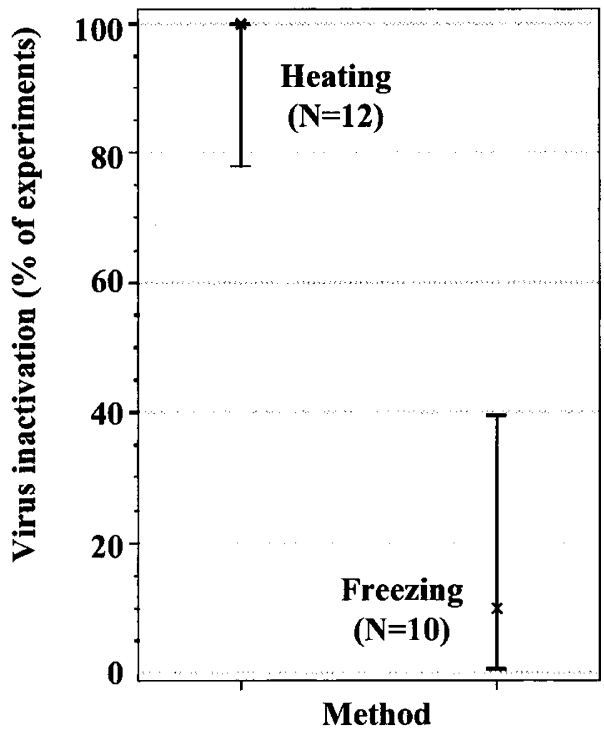

Figure 1. Virological parameters of different procedures for CMV inactivation in breast milk. (A) Stability of viral DNA after freezing or heating. $(B)$ Unimodal kinetics of CMV viral load during lactation of a maternal transmitter (see Table 1, mother C) of a term infant. The arrows indicate d 59, 66, and 87 p.p.; $\mathrm{d} 61$ : onset of viruria of the infant. (C) Virus load (infectivity) expressed as a percentage of the control for the five inactivation methods (Kruskal-Wallis test, $p=$ 0.002). Number of experiments using spiked milk (AD) / naturally infected milk (wt): $18 \mathrm{~h},-20^{\circ} \mathrm{C}, 2 \mathrm{AD} ; 4 \mathrm{~d},-20^{\circ} \mathrm{C}, 2 \mathrm{AD} / 3 \mathrm{wt} ; 10 \mathrm{~d},-20^{\circ} \mathrm{C}, 3 \mathrm{AD} ; 30$ $\min , 62.5^{\circ} \mathrm{C}, 3 \mathrm{AD} / 1 \mathrm{wt} ; 5 \mathrm{~s}, 72^{\circ} \mathrm{C}, 4 \mathrm{AD} / 4 \mathrm{wt}$. (D) Virus elimination by heating $v$ s cryoinactivation (observed percentages together with exact $95 \%$ confidence intervals; $p<0.0001)$.

\section{RESULTS}

Viral DNA load is stable after freeze-thawing and pasteurization. Initially, the influence of different inactivation procedures on viral DNA load in milk whey was studied. Neither freeze-thawing experiments storing milk for $18 \mathrm{~h}$ to $10 \mathrm{~d}$ at $-20^{\circ} \mathrm{C}$ nor Holder or short-term pasteurization reduced the viral DNA load significantly (Fig. 1A).

Determination of virus load in milk whey did not result in cytotoxicity in the microculture assay. Spiking experiments revealed a discrepancy between high viral DNA levels and low infectivity of the inoculated milk containing freeze-thawed culture supernatants of cell-free CMV laboratory strain $\mathrm{AD}$ 196 (Table 1: mother A). Interestingly, the viral DNA load (data not shown) and the virus load in naturally infected milk illustrated an unimodal course, reaching very high levels in some maternal transmitters (Fig. 1B).
Freeze-thawing and storing for various times at $-20^{\circ} \mathrm{C}$. CMV infectivity was eliminated in only 1 out of $10[95 \%$ confidence interval (CI): 0.25-44.5\%] cryoinactivation experiments (Fig. 1C). In the case of naturally infected milk (Table 1: mother C, d 87 p.p.; Fig. 1B), initial (control) viral infectivity was low compared with peak level and viral RNA could not be amplified after cryoinactivation. In contrast, in 4 out of 10 cryoinactivation experiments, virus load was incompletely destroyed and in the residual 5 cases virus load was even enhanced up to 3.8-fold in relation to the control level (Fig. $1 C)$. Interestingly, infectious virus was also detectable in milk fat of naturally infected milk during maximum of viral load (Table 1, mother C: d 59 p.p.). In this case, cryoinactivation resulted also in an enhanced infectivity in the creamy top layer. In Figure 2, viral plaque formation after freeze-storing of spiked milk for $10 \mathrm{~d}$ at $-20^{\circ} \mathrm{C}$ is shown. Although viral 


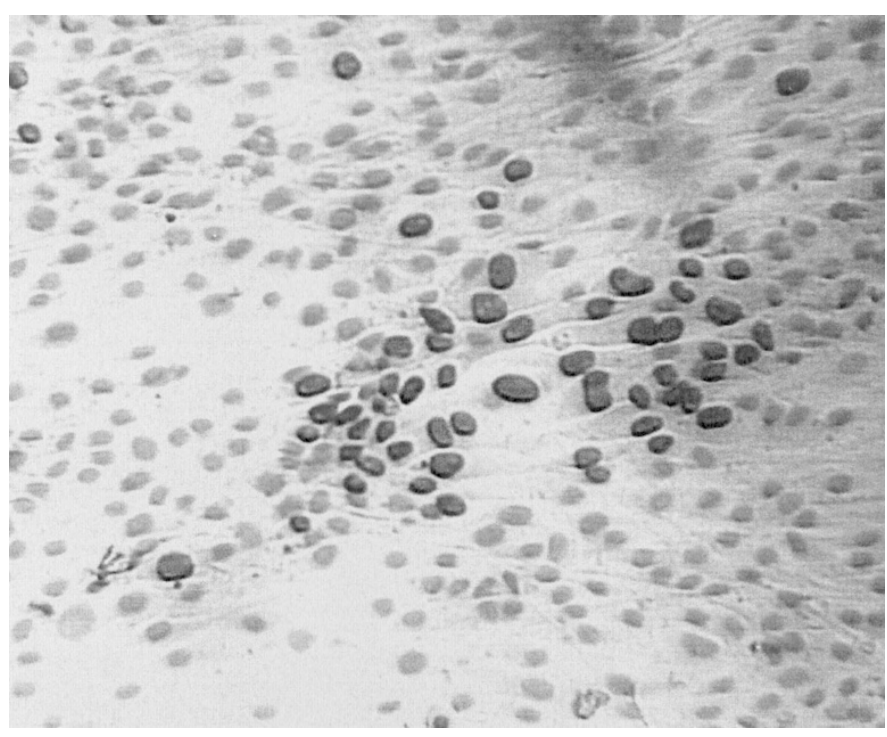

Figure 2. Freezing is insufficient for inactivation of CMV infectivity: detection of plaque-forming virus after freeze-storing of spiked milk. Native seronegative milk was spiked with $10^{5} \mathrm{TCID}_{50} / \mathrm{mL}$ CMV laboratory strain AD196 and stored for $10 \mathrm{~d}$ at $-20^{\circ} \mathrm{C}$. After thawing, milk whey was prepared and inoculated on microculture-monolayers of HFF. After incubation for $5 \mathrm{~d}, \mathrm{CMV}$ IEA staining was performed (13). Intranuclear staining of CMV IEA (brown) revealed replication competent virus with plaque formation. Control: spiked milk without freezing, 150 plaques/microculture; freeze-thawed milk: 29 plaques/microculture. Counterstaining of noninfected fibroblast nuclei (blue) was performed using Mayer's hemalum/hematoxylin solution (13).

infectivity was reduced by about $80 \%, 29$ plaques were still detectable per microculture. This demonstrates impressively that high viral loads in milk are reduced very insufficiently by freeze-storing for $10 \mathrm{~d}$.

Long-term (Holder) and short-term heat treatment. In contrast to freeze-thawing, heat treatment of human milk was able to kill CMV in each stage of lactation (Fig. 1C, Table 1). Infectivity was completely destroyed in six initial experiments using $72^{\circ} \mathrm{C}$ for $10 \mathrm{~s}$ (data not shown), therefore all subsequent experiments with short-term pasteurization were performed by heating at $72^{\circ} \mathrm{C}$ for $5 \mathrm{~s}$. Holder $(n=4)$ and short-term pasteurization $(n=8)$ were powerful tools to kill CMV in each of the 12 heat inactivation experiments $(100 \%$; 95\% CI: $73.5-$ $100 \%$ ). CMV infectivity and CMV-RNA were completely eliminated. Comparison of virus elimination by freeze-thawing and heating revealed highly significant differences $(p<$ 0.0001) (Fig. 1D).

Biochemistry. Biochemical analysis of milk whey after the various inactivation procedures did not reveal any significant alteration of $\log$ (sample/control) values for total protein, folic acid, and vitamin B12 (data not shown). Freezing for $4 \mathrm{~d}$ and $10 \mathrm{~d}$ at $-20^{\circ} \mathrm{C}$ did not alter the activity of the marker enzymes AP and lipase or the levels of sIgA (Fig. 3, $A, B$, and $D$ ). Lysozyme levels were slightly reduced (Fig. $3 C$ ). In contrast, both heat-inactivation procedures completely destroyed the activity of AP and lipase (Fig. 3, $A$ and $B$; Table 1). Holder pasteurization and short-term heat inactivation reduced lysozyme levels to $65 \%$ and $80 \%$ of the control, respectively (Fig. $3 C$ ). Both heat-inactivation procedures reduced levels of sIGA to $80 \%$ of the control (Fig. $3 D$ ).
Short-term inactivation below $72^{\circ} \mathrm{C}$. Preliminary data on the influence of our short-term heating procedure using ramp temperatures below $72^{\circ} \mathrm{C}$ derived from an additional spiking experiment (Table 2). All ramp temperatures resulted in successful virus killing. However, Holder pasteurization, like short-term heating for $2 \mathrm{~s}$ at $72^{\circ} \mathrm{C}$, destroyed the activity of AP and lipase nearly completely. In contrast, short-term inactivation for $2 \mathrm{~s}$ at $62^{\circ} \mathrm{C}$ was able to preserve up to $57 \%$ of AP activity and $10 \%$ of lipase activity (Table 2 ).

\section{DISCUSSION}

Current recommendations on freezing $(5,6)$ as well as a recent clinical study outlining routine freezing of breast milk at $-20^{\circ} \mathrm{C}$ to prevent $\mathrm{CMV}$ transmission (11) are based on former data using conventional cell culture of unseparated milk samples $(8,9)$. Our study reassessed the effectiveness of CMV inactivation procedures in human breast milk using very sensitive tools. Additionally, a new short-term heat inactivation method based on the generation of a milk film for rapid temperature exchange was presented.

Cell-free CMV is shed according to unimodal and selflimited kinetics into milk during lactation (13) and the presence of cell-free viral DNA in milk whey is the gold standard for detection of CMV reactivation during lactation $(12,13)$. However, using quantitative PCR in combination with milk fractionation, we could demonstrate the stability of CMV DNA against freeze-thawing and short- and long-term pasteurization. Therefore, DNA PCR is not able to evaluate the success of CMV inactivation methods, inasmuch as even high viral DNA loads reflect only the presence of replication-incompetent virus particles in milk whey (13). The observed discrepancy between high viral DNA load and low viral infectivity of spiked milk specimens may be explained by the heterogenous composition of cell-free culture supernatants as published by Topilko and Michelson (15). Their ultrastructural analysis of cell-free CMV culture supernatants revealed that only $38 \%$ of the particles in the extracellular virus stock inoculum consisted of complete virions (15). Therefore, only the combination of the highspeed, centrifugation-based microculture assay in conjunction with the NASBA technique enabled us to accurately determine the success of any virus inactivation step by sensitive detection of CMV infectivity and late CMV mRNA (13).

We present the first longitudinal course of quantitative virolactia of a breast-feeding mother of a term infant. Like mothers of preterm infants, the dynamics of CMV reactivation during lactation also illustrates unimodal kinetics (13). The success of freeze-thawing strongly depends on the level of cell-free virolactia at the time of inactivation, as shown in three independent freeze-storing experiments during peak level $(\mathrm{d}$ 59 p.p.) and decreasing viral loads (d 66 and 87 p.p) of a lactating maternal transmitter. Freezing is not sufficient to kill $\mathrm{CMV}$ during maximum virolactia. Moreover, even in the phase of decreasing viral load, freezing is not able to completely destroy viral infectivity. Only at the beginning and the end of viral reactivation during lactation does freezing result in complete inactivation of low CMV loads. The clinical relevance of this important issue resulting in a symptomatic CMV infection 
Table 1. Synopsis of virological and biochemical raw data after CMV inactivation of artificially and naturally infected milk

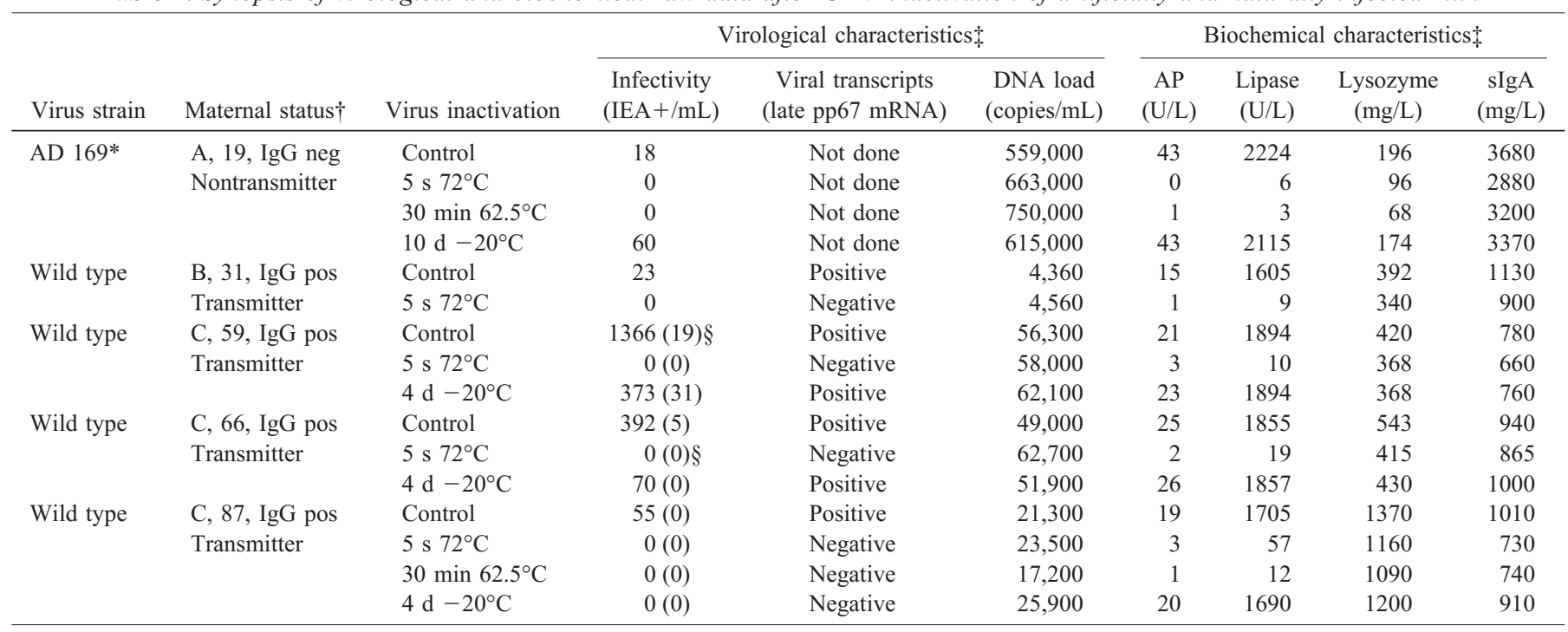

* In case of seronegative mother: spiking experiment with $10^{5}$ tissue culture infective dose $50 \%$ of CMV laboratory strain $\mathrm{AD} 169$ per $\mathrm{mL}$ of raw milk $\left(\mathrm{TCID}_{50} / \mathrm{mL}\right)$.

$\dagger$ Individual mothers (A-C), milk donation on day post partum (p.p.), anti-CMV serostatus, and retrospective characterisation as maternal transmitter or nontransmitter.

\$ Data derived from milk whey.

$\S$ Milk fat analysis (data in parentheses).

of a preterm infant exclusively fed with frozen milk could be demonstrated (16). As reported recently, initial freeze-thawing of milk may reduce the transmission rate to preterm infants (17), but it is important to consider that the CMV reactivation during lactation is a unimodal process with a peak load of DNA-lactia $(13,17)$ and virolactia $(13)$, which is associated with the initial detection of virus shedding into the urine of the preterm infants (13). Even during maximum viral load, preservation of milk at $-20^{\circ} \mathrm{C}$ for an undefined time (17) may be a risk for VLBW infants under high risk to acquire a symptomatic CMV infection. In $50 \%$ of the experiments using freeze-thawing of spiked milk samples, we observed enhanced viral load in milk whey prepared after freeze-thawing, as shown also in one case for the milk fat fraction of a naturally infected milk. An explanation could be the different distribution of laboratory strain AD169 and wild-type virus between the aqueous milk whey and the fat fraction after freezethawing. Even after storing naturally infected milk for $1 \mathrm{y}$ at $-20^{\circ} \mathrm{C}$ followed by three freeze-thawing cycles in total, we were still able to isolate infectious virus from milk whey (16). Up until now, a threshold level of CMV DNA lactia and virolactia resulting in transmission of CMV by breast-feeding cannot be given. In fact, our results indicate that even quantitative CMV DNA lactia cannot be taken as a reliable indicator of viable infectious virus in milk or milk whey after the different inactivation procedures, because DNA levels do not alter significantly. Therefore, the presence of viral pp67 late mRNA detected by NASBA in cell-free milk whey after freeze-thawing is an important molecular approach to confirm the results of quantitative virolactia by microculture. Furthermore, quantification of viral pp67 mRNA by NASBA $(14,18)$ in naturally infected milk may provide a more suitable alternative that requires further analysis.
Freezing did not alter the activity of AP and lipase or the levels of sIgA. As reported previously, storage of milk by deep-freezing at $-20^{\circ} \mathrm{C}$ for 3 mo produced no appreciable loss of lysozyme and IgA (19). Taken together, cryoinactivation preserved the nutritional quality of human milk, but unfortunately also CMV infectivity. In contrast, Holder pasteurization and short-term heat inactivation for $5 \mathrm{~s}$ at $72^{\circ} \mathrm{C}$ destroyed the activity of the marker enzymes AP and lipase completely.

Compared with freezing only, heat treatment may eliminate viral infectivity in milk in each stage of lactation, reflecting the unimodal kinetics of CMV reactivation during lactation. Feeding of freeze-stored milk from a seropositive mother with an unknown virus load to a VLBW preterm infant under risk may be associated with CMV transmission and acquisition of a symptomatic CMV infection. Only screening for (quantitative) DNA-lactia, RNA-lactia, or virolactia may predict mothers under risk to transmit the virus.

Preliminary data from short-term heat inactivation using ramp temperatures below $72^{\circ} \mathrm{C}$ revealed that $\mathrm{CMV}$ infectivity was eliminated very efficiently, preserving up to $56 \%$ of the activity of the AP. However, further clinical trials are necessary to characterize the superiority of our short-term heat inactivation method based on the generation of a thin milk film using a ramp temperature below $72^{\circ} \mathrm{C}$ compared with traditional Holder pasteurization. Thus, the lowest optimal temperature and time for complete destruction of viral infectivity and for simultaneous conservation of the nutritional and immunologic milk quality still remains to be defined. In contrast to freeze-storing, Holder pasteurization and short-term heat treatment need special equipment. Long-term pasteurization is commercially available, whereas our short-term heat procedure has been performed with a prototype. Therefore, further efforts are necessary to develop commercially available technical 

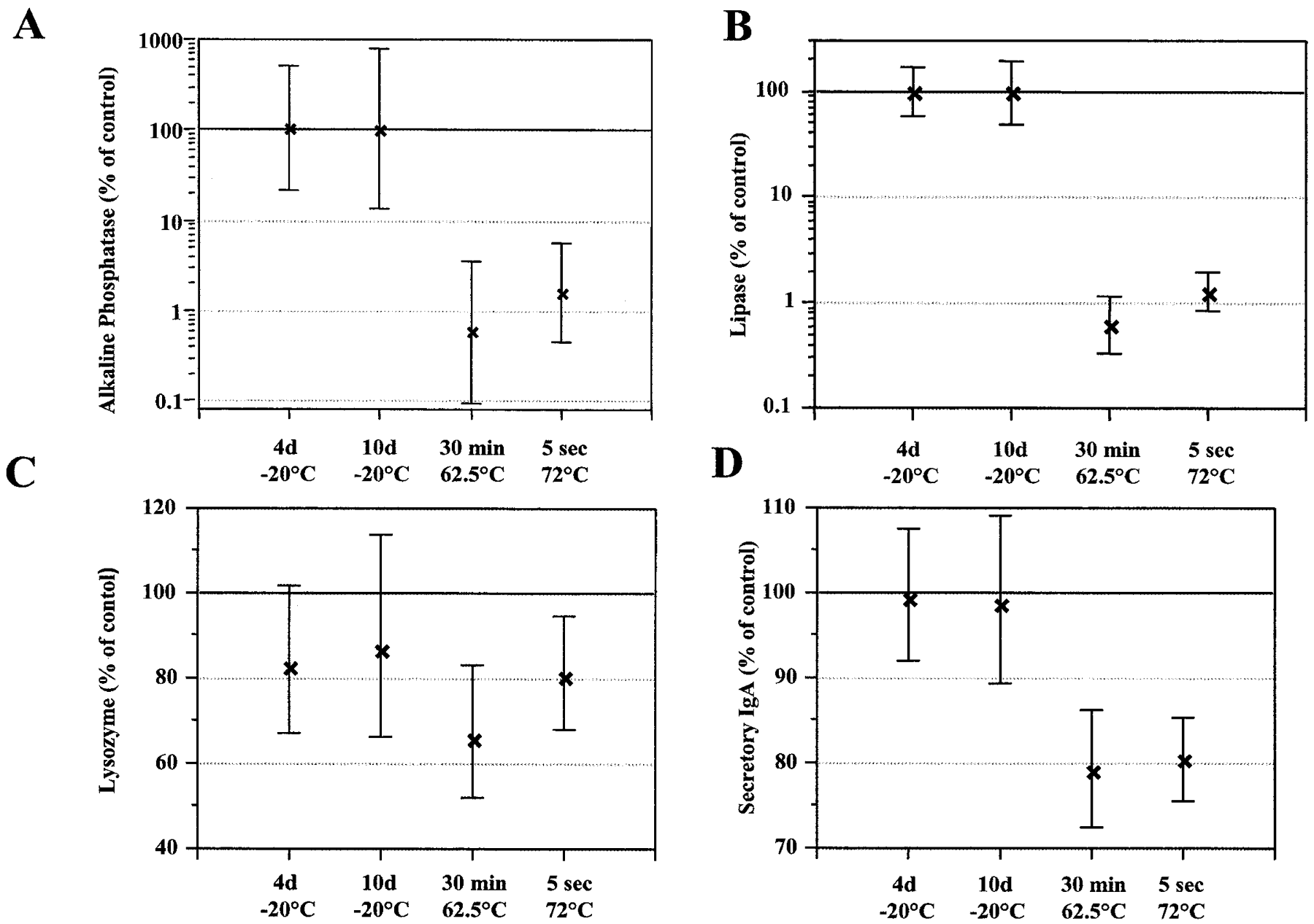

Figure 3. Biochemical parameters of different procedures for CMV inactivation in breast milk. $A-D$ show the geometric mean values together with their $95 \%$ confidence limits of four biochemical parameters expressed as percentage of control for four inactivation methods. $(A, B)$ Stability of marker enzyme activities of AP and lipase by freeze-storing, complete loss of marker enzyme activities by Holder pasteurization and short-term pasteurization. $(C)$ Moderate loss of lysozyme levels (about 20\%) by freezing and short-term pasteurization. (D) No loss of sIgA levels by freezing, moderate loss of sIgA by Holder and short-term pasteurization (about 20\%).

Table 2. Short-term heating is less harmful to the activity of marker enzymes in milk than Holder pasteurization

\begin{tabular}{|c|c|c|c|c|c|c|c|c|}
\hline \multirow[b]{2}{*}{ Virus strain } & Mother & \multirow[b]{2}{*}{ Virus inactivation } & \multicolumn{2}{|c|}{ Virological characteristics* } & \multicolumn{4}{|c|}{ Enzyme activity } \\
\hline & Lactation days p.p. & & $\begin{array}{c}\text { Infectivity } \\
(\text { IEA }+/ \\
\text { mL) }\end{array}$ & $\begin{array}{l}\text { DNA load } \\
\text { (copies } / \mathrm{mL} \text { ) }\end{array}$ & $\begin{array}{c}\mathrm{AP} \\
(\mathrm{U} / \mathrm{L})\end{array}$ & $\%$ activity & $\begin{array}{c}\text { Lipase } \\
\text { (U/L) }\end{array}$ & $\%$ activity \\
\hline \multirow[t]{4}{*}{$\mathrm{AD} 169 \dagger$} & $\mathrm{D}, 139$ & Control & 1260 & 92,500 & 23 & 100 & 59 & 100 \\
\hline & CMV-IgG negative & $2 \mathrm{~s} 72^{\circ} \mathrm{C}$ & 0 & 105,000 & 1 & 4.4 & 4 & 6.8 \\
\hline & & $2 \mathrm{~s} 65^{\circ} \mathrm{C}$ & 0 & 112,000 & 3 & 13.0 & 7 & 11.9 \\
\hline & & $30 \min 62.5^{\circ} \mathrm{C}$ & 0 & 108,000 & 1 & 4.4 & 3 & 5.1 \\
\hline
\end{tabular}

* Data from milk whey.

$\dagger$ Spiking experiment with $10^{5}$ tissue culture infective dose $50 \%$ of CMV laboratory strain AD 169 per milliliter of raw milk $\left(\mathrm{TCID}_{50} / \mathrm{mL}\right)$.

equipment for an optimized short-term heat inactivation of CMV in human milk, which overcomes the known biochemical disadvantages of Holder pasteurization resulting in prevention of CMV transmission to VLBW infants by breast-feeding. The actual debate on the importance of prevention strategies for symptomatic CMV primary infections of preterm infants under risk $(4,11,17)$ resulted recently in a consensus paper of the Austrian Society of Pediatrics that recommended Holder pasteurization of every seropositive milk up to the end of gestational wk 34 of the preterm infant (20).

Acknowledgments. The authors thank Andrea Baumeister and Elfriede Mikeler for expert technical assistance. We also thank the mothers for their generous donation of milk, and Pierre Kyme (Institute of Medical Microbiology, Tübingen, Germany) for a critical reading of the manuscript. 


\section{REFERENCES}

1. Schanler RJ, Hurst NM, Lau C 1999 The use of human milk and breastfeeding in premature infants. Clin Perinatol 26:379-398

2. Hamprecht K, Maschmann J, Vochem M, Dietz K, Speer CP, Jahn G 2001 Epidemiology of transmission of cytomegalovirus from mother to preterm infant by breastfeeding. Lancet 357:513-518

3. Maschmann J, Hamprecht K, Dietz K, Jahn G, Speer CP 2001 Cytomegalovirus infection of extremely low-birth weight infants via breast milk. Clin Infect Dis 33:1998-2003

4. Bryant P, Morley C, Garland S, Curtis N 2002 Cytomegalovirus transmission from breast milk in premature babies: does it matter? Arch Dis Child Fetal Neonatol Ed 87:F75-F77

5. Lawrence RA, Howard CR 1999 Given the benefits of breastfeeding, are there any contraindications? Clin Perinatol 26:479-490

6. Lawrence RM, Lawrence RA 2001 Given the benefits of breastfeeding, what contraindications exist? Pediatr Clin North Am 48:235-251

7. Welsh JK, Arsenakis M, Coelen RJ, May JT 1979 Effects of antiviral lipids, heat and freezing on the activity of viruses in human milk. J Infect Dis 140:322-328

8. Dworsky M, Stagno S, Pass RF, Cassady G, Alford C 1982 Persistence of cytomegalovirus in human milk after storage. J Pediatr 101:440-443

9. Friis H, Andersen HK 1982 Rate of inactivation of cytomegalovirus in raw banked milk during storage at -20 degrees $C$ and pasteurization. BMJ 285:1604-1605

10. Goldblum RM, Dill CW, Albrecht TB, Alford ES, Garza C, Goldman AS 1984 Rapid high-temperature treatment of human milk. J Pediatr 104:380-385

11. Sharland M, Khare M, Bedford-Russell A 2002 Prevention of postnatal cytomegalovirus infection in preterm infants. Arch Dis Child Fetal Neonatal Ed 86:F140
12. Hamprecht K, Vochem M, Baumeister A, Boniek M, Speer CP, Jahn G 1998 Detection of cytomegaloviral DNA in human milk cells and cell free milk whey by nested PCR. J Virol Methods 70:167-176

13. Hamprecht K, Witzel S, Maschmann J, Dietz K, Baumeister A, Mikeler E, Goelz R, Speer CP, Jahn G 2003 Rapid detection and quantification of cell free cytomegalovirus by a high-speed centrifugation-based microculture assay: comparison to longitudinally analyzed viral DNA load and pp67 late transcript during lactation. J Clin Virol 28:303-316

14. Greijer AE, Verschuuren EA, Harmsen MC, Dekkers CA, Adriaanse HM, The TH, Middeldorp JM 2001 Direct quantification of human cytomegalovirus immediateearly and late mRNA levels in the blood of lung transplant recipients by competitive nucleic acid sequence-based amplification. J Clin Microbiol 39:251-259

15. Topilko A, Michelson S 1994 Morphological and cytochemical analysis of human cytomegalovirus inoculum: correlation of free particles in inoculum with counterparts in infected cells. Res Virol 145:65-73

16. Maschmann J Freeze-thawing of breast milk does not prevent cytomegalovirus transmission to preterm infants. Arch Dis Child, in press

17. Yasuda A, Kimura H, Hayakawa M, Ohshiro M, Kato Y, Matsuura O, Suzuki C, Morishima T 2003 Evaluation of cytomegalovirus infections transmitted via breast milk in preterm infants with a real-time polymerase chain reaction assay. Pediatrics 111:1333-1336

18. Greijer AE, Adriaanse HM, Dekkers CA, Middeldorp JM 2002 Multiplex real-time NASBA for monitoring expression dynamics of human cytomegalovirus encoded IE1 and pp67 RNA. J Clin Virol 24:57-66

19. Evans TJ, Ryley HC, Neale LM, Dodge JA, Lewarne VM 1978 Effect of storage and heat on antimicrobial proteins in human milk. Arch Dis Child 53:239-241

20. Zwiauer K, Deutsch J, Goriup U, Haas H, Haiden N, Holzmann H, Pietschnig B, Pollak A, Popow T, Rock I, Sperl W, Widhalm K 2003 Prävention von Muttermilch-mediierten CMV-Infektionen bei Frühgeborenen. Monatsschr Kinderheilkd. 151:1346-1347 